\title{
Discourse War on NKRI versus Khilafah Issues in Indonesian Cyber Media
}

\author{
Moch. Syarif Hidayatullah \\ Translation Department \\ Syarif Hidayatullah State Islamic University Jakarta, Indonesia \\ moch.syarif@uinjkt.ac.id
}

\begin{abstract}
This paper focuses on NKRI (Negara Kesatuan Republik Indonesia/ The Unitary State of the Republic of Indonesia) versus Khilafah issues in Indonesian cyber media. It was represented by hizbut-tahrir.or. id (representing HTI and other radical groups), nu.or.id (representing $\mathrm{NU}$ and moderate groups), and islamlib.com (representing JIL and other liberal groups). The study aims to examine tendency, intensity, discourse functions, and language styles on news and articles in the sites. Discourse Analysis and Content Analysis will be used to dismantle the contents of all sites on the issue of NKRI and Khilafah. It is known that NU (Nahdlatul Ulama, the biggest Islamic organizations in Indonesia) and HTI (Hizbut Tahrir Indonesia) sites have a tendency to always differ on the issue of Khilafah ideology. JIL (Jaringan Islam Liberal; Islam Liberal Network) site was not the main source for news and articles of Khilafah. HTI site is more numerous and more diverse in developing the ideology of Khilafah. This is natural because HTI site has a primary mission to campaign for Khilafah ideology and counteract all different views. It is also known in discourse functions that the sites commonly use directive function and referential function. In the language style, the sites use persuasive more than narrative. Denotative meaning is more condensed than connotative meaning. The titles in some of the articles look more straightforward and provocative.
\end{abstract}

Keywords - Indonesian cyber media; discourse war; Khilafah; cyber Islam

\section{INTRODUCTION}

The issue of the Khilafah has long been a debate within Islam. Khilafah is also the root of the problem that initially caused the division within the Muslim communities, resulting in the emergence of Islamic political factions and triggered the birth of religious schools, such as Khawarij, Shia and Murjiah [1, p. 252]. (Historically, this term began to be used practically after the death of Prophet Muhammad. This term was previously found only in the Qur'an and hadith. The scholars differ on whether the verses and hadiths that have this word and its derivative contain the link between religious affairs and political affairs. According to Ibn Taimiyyah, some of these words mean leadership (imamah) or kingdom (mamlakah) in the general sense, and have absolutely nothing to do with divine command such as nubuwwah rapture [2, p. 135]. Meanwhile, several other scholars say that some of these words have direct links that combine religious affairs and political affairs[3, p. 41]. These two groups havean equally strong argument. Ibn Taymiyya, for example, says that some of these words only mean as power is replaced. Therefore, if anyone interpreted some of these words with careful interpretation and adopted the important political theories of his interpretation, then indeed he has lowered the divine revelation and the historical reality [2, p. 140]. This is because many of those words which, if interpreted with political notions become meaningless.

If later there are parties who want to revive the terms and systems of the Khilafah as part of Islamic political entity, they must be aware of the facts and opinions. This is not to mention the historical record of the collapse of the Ottoman Empire in the early 20th century. That means those who want to live this term are actually just doing-in Hobsbawm and Ranger [4] term - the invention of tradition.

One of the Islamic organizations in Indonesia aggressively campaigning for the use of the concept of Khilafah is Hizbut Tahrir Indonesia (HTI). Before being banned, its official website (which is currently closed) openly opposes the concept of NKRI because it is not in accordance with Islamic teachings. This led to a response from the official website of NU and JIL. The case so far has not been widely studied by other researchers and is expected to open a veil of a question mark about the reasons behind the Government ban on HTI.

\section{METHOD}

This paper will observe, describe, analyze, and explain the contents of the sites about NKRI versus Khilafah issues. In general, the method used in this research is the method to examine the electronic data. In some analysis, I use the same method with which one I used in my article about sectarianism ideology on Islamic online media in Indonesia [5]. Although there is a difference in this paper: that is the discourse function and language style analysis, which is not found in the previous articles. The main data sources in this study are the editorial and the content of hizbut-tahrir.or.id, nu.or.id, and islamlib.com. The selection of these sites is based on the available columns and articles which contain contents about NKRI versus Khilafah issues.

This research utilizes content-oriented approach in exposing the discourse discussed in the article or news. A structure- oriented approach is not used in this study due to 
the diverse and heterogeneous data. To extract the topics in articles and news items studied, this research uses headlines and editorial articles as a guide to see the topics developed by the site administrator to manage the issue in order to understand his tendency and intensity.

In this study, content analysis is made as the additional science which is used to reveal the content of sites, so as to identify the identity and ideology of the site administrators or content filler. The Content Analysis itself is a scientific methodology which is used in the field of humanities to review the authorship, authenticity, or meaning. Palmquist [6] asserted that content analysis is a research device which is focused on actual content and internal features of a media which takes a look at the use of words, concepts, themes, phrases, characters or sentences in a text or a group of texts. The text here can be in the form of books, chapters in a book, essays, discussions, editorial and articles, historical documents speeches, conversations, advertisement, shows, informal conversations or any language/means of communication.

There is another important thing to consider in viewing the discourse, which is related to the various discourse functions. Jakobson [7] mentions there are six functions of discourse. First, the emotive function. This function is used to express the emotions, desires, or feelings of messengers, which are individual. Second, the directive function. This function is used to influence others, both emotions, feelings, and behavior, by giving information, inviting, ordering, reminding and threatening. Third, the referential function. This function is used to inform something, such as reporting, describing, explaining and informing something. Fourth, metalingual function. This function is used to symbolize other codes, such as to define something.

Fifth, the function of fatis. This function is used to organize, open and facilitate communication. Sixth, the poetic function. This function is used to show aesthetic and artistic elements, such as rhythm, rhyme, and metaphor. Meanwhile, in terms of language, there are four types of language styles [8, p. 116]. First, the style of language is based on word choice. The author chooses the style of the language according to the situation of the conversation. Second, the language style based on the tone, which often influences each other and can form a distinctive style of language. Third, the style of language is based on sentence structure. Fourth, the style of language is based on the directness and the absence of meaning. An author may choose words to be used in his literary works with denotative or connotative meanings.

\section{RESULT AND DISCUSSION}

The analysis in this section will focus on mapping the discourse wars conducted by the sites on the khilafah issue. For the restriction of a large amount of scattered data related to the issue of khilafah on all sites, this research will only limit the articles and news revealed in the period 2011-2015. The analysis is only on articles and news that include the word khilafah and NKRI as the title. Articles and news must also be related to Indonesia.

The results in the search field by entering the khilafah keyword as an entry, obtained 289 articles and news that discuss the issue of khilafah on the nu.or.id (NU), 60 articles and news on the islamlib.com (JIL), and 10,418 data (articles, news, comments, and photos) on the hizbut-tahrir.or.id (HTI). Meanwhile, by entering the NKRI keyword as an entry, obtained 2128 articles and news discussing the NKRI issue on the NU, 26 articles and news on JIL (in timeline column: 84 data), and 241 data (articles, news, comments, and photos) on the HTI. Although the results in the search field by entering the "NKRI dan Khilafah" keyword, obtained only 22 articles and news discussing the NKRI issue on the NU, 1 article on JIL, and 3 articles on the HTI.

Here is the data from the NU:

1. Warga Pesantren Diingatkan "Kelompok Khilafah" Ingin Runtuhkan NKRI (17/8/2015)

2. Gerah Wacana Khilafah, PMII IAIN Jember Surati SKPD (12/6/2015)

3. Aliran Pengusung Khilafah Tak Boleh Eksis di Indonesia (24/3/2015)

4. Kiai ini Pasang Logo NU di Rumahnya sebagai Penangkal HTI (11/3/2015)

5. Begini Cara HTI Rekrut Anggota dari Ibu-ibu Muslimat NU (12/2/2015)

6. Mahfud MD: Ideologi Khilafah Sempat Diusulkan sebagai Dasar Negara (1/2/2015)

7. Materi dan Kekuasaan Jadi Tujuan Utama Pengusung Khilafah (29/1/2015)

8. NU Pasuruan Minta TNI Tegas Hadapi Ormas Khilafah (15/1/2015)

9. Ulama Tangerang Raya Keluarkan Fatwa Haram Dukung Khilafah (11/11/2014)

10. Cerita Aktivis Muslimat Bersinggungan dengan HTI (20/10/2014)

11. GP Ansor Riau Ingatkan Kampus Jaga NKRI dari HTI (17/10/2015)

12. Gemasaba Akan Surati Kemendagri, Bubarkan HTI (23/9/2014)

13. KH Marzuki Mustamar: Kader NU Wajib Jaga NKRI (13/8/2014)

14. Terkait Konferensi Khilafah, HTI Bohongi Polisi (2/6/2014)

15. Kiai Muchit Muzadi: Penegakan Syariat Islam Ancam NKRI (18/5/2014)

16. Pemerintah RI Abai Terhadap Gerakan Khilafah (5/8/2013)

17. MPR RI Dorong Pemerintah Tindak Tegas Gerakan Khilafah (4/8/2013)

18. Muktamar Khilafah HTI, Penyimpangannya, dan NKRI (16/6/2013)

19. Berkat Ulama NU NKRI Berdiri (18/6/2012)

20. Ketua PCNU Sumenep: Bukan saatnya lagi Bicara Khilafah (1/6/2012)

21. Kang Said: Komitmen ke NKRI, NU Tolak Pendirian Negara Islam (22/9/2011)

22. NU Jatim Minta Pemerintah Bubarkan Ormas Penganjur 


\section{Khilafah (10/7/2011)}

On the other hand, on the Islamlib only found one article entitled "NKRI Sudah Final" (9/6/2010). Although the article is closely related to this issue, it is unfortunately written outside the period of this research. Meanwhile, there are three articles related to this issue derived by the HTI which is reflected in the following articles:

1. Tidak Mengancam NKRI (31/8/2015)

2. Bohong Jika Demokrasi Menjaga Keutuhan NKRI (10/2/2014)

3. Siapa yang Membahayakan NKRI? (13/6/2011)

From the raw data, at least it appears that HTI has more articles in the topic of khilafah compared to the other two sites. This is understandable because the khilafah issue is the main "selling" of HTI. In contrast to NU and JIL that does not make the issue of khilafah a central issue. Meanwhile, related to the NKRI issue, NU looks much more dominant than the other two sites. This at least in discourse, NU has a great attention to this issue compared to the other two sites.

Based on Palmquist theory, it is known that NU is more and more assertive in explicitly campaigning that the Khilafah is a threat to the NKRI. HTI seem to be quite cautious in responding to this issue. This is seen from the number of articles that are slightly related to this issue. On those articles, HTI tried to dispute that the ideology of the Khilafah is a threat to the NKRI. Meanwhile, on the Islamlib for five years there has been no article or news on this issue, although this does not mean that JIL sites have no concern for this issue. As explained earlier, there is an article entitled "NKRI Sudah Final" (NKRI is Undisputed) in 2010, which clearly rejects the ideology of the Khilafah carried by HTI. This all proves that what the sites do on this issue do not stand alone. It becomes part of the interests of the owner or manager of this site on this issue, which is certainly related to the interests of organizations behind it.

In discourse functions, the sites are both utilizing the directive and referential functions. The function of the directive is seen from the way these sites take advantage of the issue of "Khilafah versus NKRI" to try to influence their readers' emotions, feelings, and behaviors from the titles they make by attempting to annotate, invite, order, order, remind, and threaten. The referential function is also seen from the way the sites are informing this issue in its reportages, descriptions, explanations, and information. In language style, it appears that the persuasive is more dominant than the narrative. The meaning sent in the form of direct language style. Its denotative meaning is more viscous than connotative meaning. Some titles look more straightforward and tend to be provocative. On this issue, the NU website displays some of the names cited by its opinion, such as Mahfud MD, K.H. Muchit Muzadi, K.H. Marzuki Mustamar, and K.H. Said Aqil Siradj.

Another thing that also needs to be discussed in this context is why the HTI fight for this Arabic term, then consider it as fighting for Islam and reject the concept of
NKRI? This is certainly not a coincidence. Islam revealed in Arabic is the factor. According to Azra [9] (in Lewis 1994: $\mathrm{xx}$ ), the Qur'an and hadith as the main source of Islam using Arabic have been the origin of almost all idioms, terms, and even political jargons. The adoption of idioms, terms, and jargons of Arabic- speaking Islamic politics can no longer be avoided by Islamic societies outside the Arab region. In fact, the idioms, terms, and jargons are related to Muslim experience on the Arabian Peninsula that does not have to be in harmony with the basic concepts outlined by the Qur'an and hadith. Not infrequently also the meaning has shifted from the initial meaning when the idioms, terms, and jargons ware introduced.

\section{CONCLUSION}

Based on the topic analysis, it is known that NU and HTI sites have a tendency to always differ on the issue of Khilafah ideology. JIL site was not the main source for news and articles of Khilafah. It is understandable because the JIL site is not only focused on responding this issue. However, sporadically, essentially JIL rejects the Khilafah system. Each site also differs in the level and intensity of the news. In the analysis of cyberspace discourse, the number signifies the focus of the site management. The more often a particular issue or topic is raised, the higher the site's attention to a particular issue is. In general, HTI site is more numerous and more diverse in developing the Khilafah ideology. This is natural because HTI site has a primary mission to campaign for Khilafah ideology and counteract all different views. The use of direct language, persuasive, denotative, and provocative meanings is often found in cyber media, because in this way the owners or administrators can usually make it easier to bring visitors and lure the readers to share the content.

\section{REFERENCES}

[1] Ahmad Amin, Fajr al-Islam. Beirut: Dar al-Kutub al-Arabi, 1969.

[2] Q. Khan, Pemikiran Politik Ibnu Taymiyyah. Bandung: Pustaka, 1995.

[3] B. Lewis, The Political Language of Islam. Chicago and London: The University of Chicago Press, 1988.

[4] E. Hobsbawm and T. Ranger, The Invation of Tradition. Cambridge: Cambridge University Press, 1992.

[5] M. S. Hidayatullah, "The Sectarianism Ideology of the Islamic Online Media in Indonesia,"' Insaniyat J. Islam Humanit., vol. 2, pp. 141-151, 2017.

[6] M. Palmquist, “Content Analysis," 1990. [Online]. Available: http://writing.colostate.edu/guides/pdfs/guide61.pdf. [Accessed: 16Feb-2017].

[7] Jakobson, "Closing Statement: Linguistics and Poetics'.," in DalamT.A. Sebeok (ed.). Style in Language., Cambridge: The MIT Press, 1960 , p. 350- 377.

[8] Gorys Keraf, Diksi dan Gaya Bahasa. Jakarta: Gramedia Pustaka Utama, 1996.

[9] Azyumardi Azra, "Kata Pengantar" in Bernard Lewis. Bahasa Politik Islam. Jakarta: Gramedia, 1994. 